\title{
Technological prerequisites for the energy efficiency increase of the engine cylinder bore processing
}

\author{
Lydmila Safarova ${ }^{1}$, Andrey Malikov $^{2}$, Alexandr Yamnikov $^{2 *}$ and Olga Yamnikova $^{3}$ \\ ${ }^{1}$ Production Association "TULAMASHZAVOD", 2 Mosin St. Tula, Russia \\ ${ }^{2}$ FGBOU VO Tula state University, Lenin Avenue, 92, Tula, 300012, Russia \\ ${ }^{3}$ JSC "NPO" SPLAV "named after A.N. Ganicheva, 33 Shteglovskaya zaseka, 300004, Tula, Russia
}

\begin{abstract}
An example of the rationalization of the current technology for manufacturing a cylinder of a small-sized diesel engine at PA "TULAMASHZAVOD" from a cast iron is given. It is shown that lowpower obsolete equipment leads to an increase in the number of technological operations and equipment used. However, even if all the generally accepted technological recommendations are followed, only $80 \%$ of the parts meet the requirements for the required parameters of accuracy and quality of the cylinder bore surface. Studies have found that the main reasons for insufficient quality are the presence of residual stresses in the casting, which cannot be removed during artificial aging, as well as insufficient accuracy and rigidity of metal cutting equipment at turning and boring operations. The use of more powerful and accurate modern equipment is theoretically and experimentally justified, which, due to increased refinement, allows reducing the number of machining operations. Replacement of artificial thermal aging by natural, combined with the replacement of shaft furnaces for heat treatment of workpieces with chamber furnaces of lower power and higher capacity, reduce energy consumption for the manufacturing by almost 4 times.
\end{abstract}

\section{Introduction}

In the modern world, serious attention is paid to "Environmental technologies". However, this has not yet spread to mechanical engineering, for example, at the conference "PromEngineering-2021" in section 1.8. "Environmental technologies in mechanical engineering" no reports were announced. When studying the energy efficiency of production, scientists usually pay attention to the essence of the workpiece processing and try to reduce energy costs by controlling the parameters of the process [1-6].

However, sometimes a change in the complex technological process of manufacturing, usually aimed at reducing the labor intensity of processing by using new, more powerful equipment, can simultaneously save the total energy costs [7-11].

\footnotetext{
*Corresponding author: yanmnikovas@mail.ru
} 
When designing a complex technology for manufacturing machine parts, the composition and number of operations, and therefore workplaces, is determined by the drawing of the part with technical requirements, the type of workpiece and the size of the allowance left for machining, as well as the efficiency of the cutting tool and the accuracy and, especially, the rigidity of the applied equipment.

When developing technological operations to achieve a specified quality of parts, attention is paid to the technological heredity appearance [10 - 12], for example, in the manufacture of a diesel engine cylinder (Fig. 1).

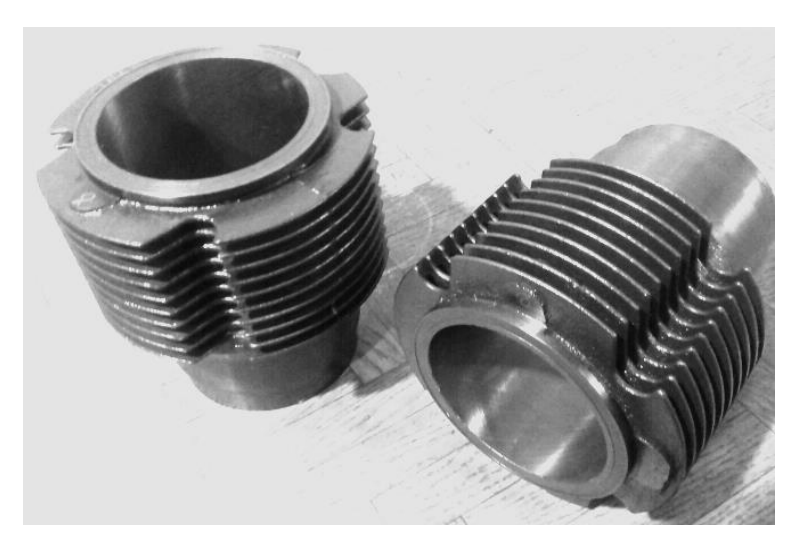

a)

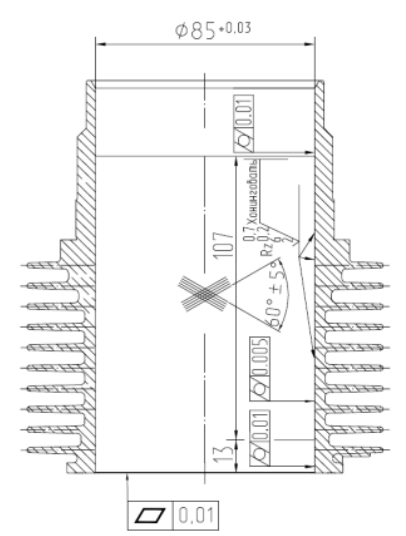

b)

Fig. 1. Diesel cylinder of the Tula machine-building plant: a) photo; b) sketch with dimensions.

The properties of the casting material and its behavior in the melt crystallization [13 15] need to be taken into account. Studies of the density distribution over the cylinder casting cross section by employees of the Tula State University and the Machine-Building Plant, carried out using X-ray computational tomography, showed that the metal in the casting had an inhomogeneous structure, the density of which varied within $6.75 \div 7.25 \mathrm{~g} /$ $\mathrm{cm}^{3}$.

Therefore, in the current technology, artificial aging is assigned as the first operation after receiving the casting. To reduce the copying of errors of the original workpiece, staged processing is used. So at PA "TULAMASHZAVOD" the following technology is used (Table 1). Castings are subjected to artificial aging in a shaft electric furnace, by heating to a temperature of $490 \div 510^{\circ} \mathrm{C}$ for 9 hours, then cooling in a furnace with an open lid to a temperature of $380 \div 400^{\circ} \mathrm{C}$, and then in the air. The parameters of the microstructure and the hardness of the sample cut from the casting are monitored in the laboratory of mechanical tests and metallography with the issuance of a certificate. Sample hardness 207 $\div 249$ HB. The "16A20F3S39" lathe with CNC and the "1R-TS95" finishing/boring machine manufactured in 1999, used in the technological process, are physically obsolete. The refinement coefficient for the turning operation was $\varepsilon_{\text {cutt }}=4$, for boring $\varepsilon_{\text {bor }}=5$. The general refinement for two successive operations, turning and boring was $\varepsilon_{\Sigma}=4 \cdot 5=20$. Taking into account the inevitable basing error for the boring operations, in reality, the processing error reaches $0.06 \mathrm{~mm}$ [7]. After blade processing, a stabilizing tempering is applied in a shaft electric furnace by heating to a temperature of $180^{\circ} \mathrm{C}$ for $4 \div 5$ hours, then cooling in the air. 
Table 1. Energy consumption of the basic technological process.

\begin{tabular}{|c|c|c|c|c|}
\hline $\begin{array}{c}\text { Operation number } \\
\text { and name }\end{array}$ & Equipment model & $\begin{array}{c}\text { Set capacity, } \\
\mathbf{k W}\end{array}$ & $\begin{array}{c}\text { Time } \\
\text { per } \\
\text { piece }\end{array}$ & $\begin{array}{c}\text { Energy } \\
\text { consumption, } \\
\mathbf{k W h}\end{array}$ \\
\hline $\begin{array}{c}\text { 0 Artificial aging of } \\
\text { the casting }\end{array}$ & Shaft electric furnace SShZ6.6/7 & 100 & $540 / 20$ & 45 \\
\hline 1 CNC lathe & CNC lathe 16A20F3S39 & 21,4 & 6,99 & 1,28 \\
\hline 0-1 Aging & Shaft electric furnace SShZ6.6/7 & 100 & $240 / 20$ & 20 \\
\hline 2 Boring & $\begin{array}{c}\text { Finishing/boring machine } \\
\text { 1R-TS95, released 1999. }\end{array}$ & 3 & 6,07 & 0,15 \\
\hline 0 - 1 Stabilizing \\
tempering & Shaft electric furnace SShZ6.6/7 & 100 & $240 / 20$ & 20 \\
\hline 3 Honing & Vertical Honing 3822OP40 & 2,2 & 7,45 & 0,27 \\
\hline 4 Honing & Vertical Honing 3822OP40 & 2,2 & 10,37 & 0,38 \\
\hline 5 Honing & Vertical Honing SS-6062 & 2 & 2,45 & 0,08 \\
\hline 6 Honing & Vertical Honing SS-6062 & 2 & 3,13 & 0,10 \\
\hline 7 Honing & Vertical Honing SS-6062 & 2 & 4,43 & 0,15 \\
\hline & Total & 40,89 & 87,41 \\
\hline
\end{tabular}

Low accuracy of the blade processing makes it necessary to leave an increased honing allowance; when such allowance is removed in one operation, the workpiece can heat up to $200^{\circ} \mathrm{C}$, which will inevitably lead to a loss of accuracy [17-19]; therefore the honing operation is divided into a total of 2 roughing and 3 finishing steps including the application of a cross-diagonal mesh of the oil pockets.

As a result, according to factory data, $80 \%$ of the parts are made within the tolerances for all dimensions of the cylinder bore:

- deviations from cylindricity up to 8 microns;

- $\quad$ the change in the size of the finished part reaches $3 \div 10$ microns.

\section{Justification of rational technology}

In item [10], it is recommended to use natural aging of castings for 6 months in the manufacture of a diesel engine cylinder, which ensures a decrease in the range of the cylinder bore dimensions after final processing from $3 \div 10 \mu \mathrm{m}$ to $0 \div 5 \mu \mathrm{m}$.

It was also decided to replace the outdated "16A20F3S39" CNC lathe with a more advanced and precise machine: the "1TNS-6008" CNC lathe.

The theoretical studies described in [7-11] gave grounds to replace two operations, diamond boring on the "1R-ST95" machine and the honing operation on the "3822OP40" vertical honing machine in the basic technological process with one operation - double boring on the ARS-4C boring machine with $\mathrm{CNC}$, the refinement at each position of which was $\varepsilon_{\text {bor }}=10$, the total refinement, respectively, $\varepsilon_{\Sigma}=10 \cdot 10=100$, that is, 5 times higher than in the basic version of the technology.

To check the declared parameters of the part after processing on the boring machine ARS-4C, a pilot batch of "Cylinders" was carried out (Table 2). 
Table 2. Geometrical parameters of the cylinder bore diameter $85 \mathrm{~mm}$ and $95 \mathrm{~mm}$, obtained by processing on a boring machine ARS-4C.

\begin{tabular}{|c|c|c|}
\hline Checked parameters & $\begin{array}{c}\text { Parameters set } \\
\text { according to the } \\
\text { newly developed } \\
\text { technological process }\end{array}$ & $\begin{array}{c}\text { Results received when processing on } \\
\text { the ARS-4C boring machine with } \\
\text { CNC (accuracy parameters), mm }\end{array}$ \\
\hline Inner diameter $85 \mathrm{~mm}$ & $\varnothing 84,92+0,05$ & $0,016 \div 0,038$ \\
\hline Inner diameter $95 \mathrm{~mm}$ & $\varnothing 94,92+0,05$ & $0,016 \div 0,025$ \\
\hline Roundness tolerance, $\mu \mathrm{m}$ & Not specified & $0,003 \div 0,02$ \\
\hline Cylindricity tolerance, $\mu \mathrm{m}$ & 10 & 0,009 \\
\hline $\begin{array}{c}\text { Radial runout tolerance of the } \\
\text { inner surface relative to the } \\
\text { outer, } \mu \mathrm{m}\end{array}$ & not specified & 0,05 \\
\hline Roughness, $\mathrm{Ra}, \mu \mathrm{m}$ & 2,5 & $1,2 \div 1,7 \mu \mathrm{m}$ \\
\hline
\end{tabular}

During the honing operation, a modern CC740B2 honing machine with CNC was introduced, featuring advanced technological capabilities: increased accuracy, automatically replaceable honing head stones and a powerful cooling system.

The errors indicated in Table 2 can be successfully removed by honing [17 - 19]. As a result of the "Cylinders" parts batch manufactured, it was concluded that it is expedient to introduce boring operation on the ARS-4C machine with $\mathrm{CNC}$ into the technological process of machining the "Cylinders" and the use of single honing. The deviations of the diameter after a single honing do not exceed $0.028 \mathrm{~mm}$, and the non-roundness does not exceed $0.006 \mathrm{~mm}$, which is within the specified tolerances.

Taking into account the positive experiences on the influence of intracycle aging operations, the following route for processing the cylinder bore of a diesel engine is proposed (Table 3).

Table 3. Energy consumption of the newly developed technological process.

\begin{tabular}{|c|c|c|c|c|}
\hline $\begin{array}{l}\text { Operation number } \\
\text { and name }\end{array}$ & Equipment model & $\begin{array}{c}\text { Set } \\
\text { capacity, } \\
\text { kW }\end{array}$ & $\begin{array}{c}\text { Time } \\
\text { per } \\
\text { piece }\end{array}$ & $\begin{array}{c}\text { Energy } \\
\text { consumption, } \\
\text { kWh }\end{array}$ \\
\hline 0 Aging of the casting & Shelving in the warehouse & 0 & $\begin{array}{c}6 \\
\text { month }\end{array}$ & 0 \\
\hline 1 CNC lathe & CNC lathe 1TNS-6008 & 26 & 6,99 & 1,51 \\
\hline $\begin{array}{l}0-1 \text { Aging of the } \\
\text { workpiece }\end{array}$ & $\begin{array}{c}\text { Chamber electric furnace } \\
\text { SNOT8.18.6/8,5M }\end{array}$ & 70 & $240 / 25$ & 11,2 \\
\hline 2 Boring & ARS-4C boring machine & 6 & 6,03 & 0,30 \\
\hline $\begin{array}{l}0-2 \text { Aging of the } \\
\text { workpiece }\end{array}$ & $\begin{array}{c}\text { Chamber electric furnace } \\
\text { SNOT8.18.6/8,5M }\end{array}$ & 70 & $240 / 25$ & 11,2 \\
\hline 3 Honing with $\mathrm{CNC}$ & $\begin{array}{l}\text { Honing machine with CNC } \\
\text { SS740V2 }\end{array}$ & 5,5 & 3,5 & 0,29 \\
\hline \multicolumn{3}{|c|}{ Total } & 16,52 & 22,5 \\
\hline
\end{tabular}

\section{Results and Discussions}

The labor intensity of manufacturing products using the new technology (Table 3) in comparison with the basic technology (Table 1) with an annual production program of 1500 units will save 609.25 working hours. 
The reduction in energy consumption for one part looks more clearly: instead of $87.41 \mathrm{kWh}$ in the basic process, we got $22.5 \mathrm{kWh}$ in the new technological process. That is, the energy is spent almost 4 times less in the new process.

It is noted [20] that: "Here, we integrate prospective life-cycle assessment with global integrated energy-economy-land-use-climate modelling to explore life-cycle emissions of future low-carbon power supply systems and implications for technology choice. Future per-unit life-cycle emissions differ substantially across technologies. For a climate protection scenario, we project life-cycle emissions from fossil fuel carbon capture and sequestration plants of 78-110 $\mathrm{g} \mathrm{CO}_{2} \mathrm{eq} \mathrm{kWh}^{-1}$, compared with 3.5-12 $\mathrm{g} \mathrm{CO}_{2}$ eq kWh${ }^{-1}$ for nuclear, wind and solar power for 2050. Life-cycle emissions from hydropower and bioenergy are substantial $\left(\sim 100 \mathrm{~g} \mathrm{CO}_{2} \mathrm{eq} \mathrm{kWh}^{-1}\right)$, but highly uncertain". Agreeing with the importance of choosing electricity generation technology, our work shows that energy savings among consumers, in particular in mechanical engineering, are of no less importance. Taking into account the carbon footprint, which amounts in Russia to $490 \mathrm{~g} / \mathrm{kWh}$ of $\mathrm{CO}_{2}$ equivalents per $1 \mathrm{kWh}$ of generated electricity, we obtain comparative graphs of $\mathrm{CO}_{2}$ emission in the basic process and the new technological process based on the annual program by types of operations: 1 - artificial aging, 2 - blade processing, 3 - honing (Fig. 2).

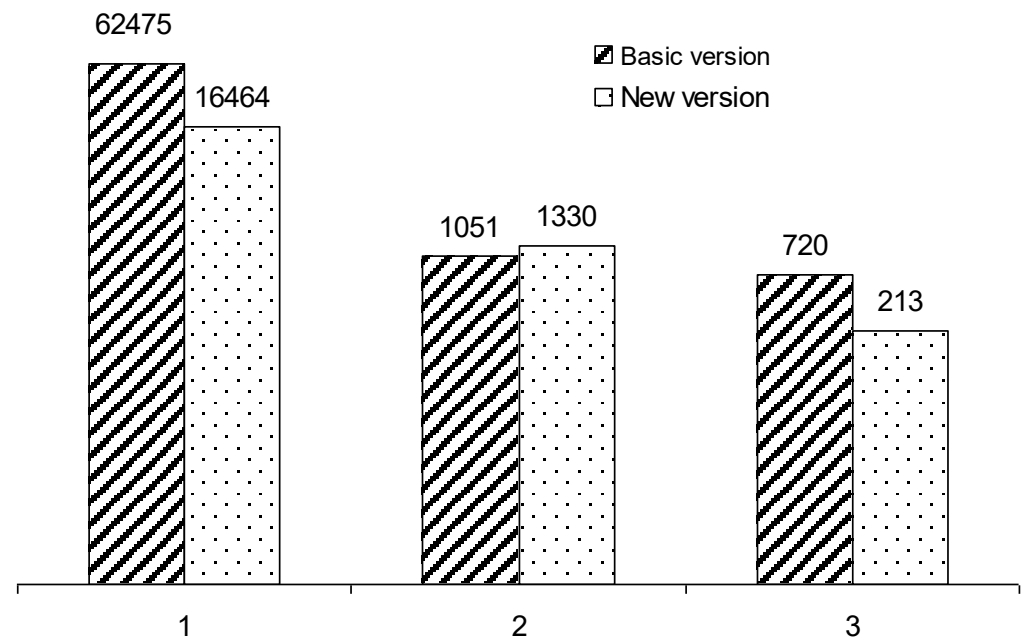

Fig. 2. Comparative graphs of $\mathrm{CO} 2$ emission in the basic process and the new technological process of cylinder manufacturing based on an annual program of 1500 pieces (in $\mathrm{kg}$ ).

The results of the work carried out show that the use of modern, more powerful, but accurate equipment, in general, makes it possible to achieve a reduction in energy consumption for the manufacture of parts in mechanical engineering. In terms of the annual cylinder production program, the total $\mathrm{CO} 2$ reduction in the new process compared to the basic process will be $64216-18007=46209 \mathrm{~kg}$.

\section{Conclusion}

The studies of the complex technological process of manufacturing of the cylinder described in the article showed that the rational construction of the sequence of processing 
the elementary surfaces of the parts in conjunction with the use of modern, more powerful and rigid metal cutting equipment leads to a reduction not only in the production time and the cost of the parts, but also in the $\mathrm{CO}_{2}$ emissions.

In the case under study, in terms of the annual cylinder production program, the total reduction in the $\mathrm{CO}_{2}$ emissions in the new technological process compared to the basic technological process will be $64216-18007=46209 \mathrm{~kg}$.

\section{References}

1. V. L. Zakovorotny, V. P. Lapshin, V. E. Gvindjiliya, N. D. Ahn, E3S Web of Conf. 104, 01017 (2019)

2. V. L. Zakovorotny, V. E. Gvindzhiliya, Russian Engineering Research, 39, 5, 423 (2019)

3. V. L. Zakovorotny, A. D. Lukyanov, Int. J. of Mechanical Eng. and Aut., 1, 5, 271 (2014)

4. V. P. Lapshin, V. V. Khristoforova, IOP Conf. Ser.: Mater. Sci. Eng. 900012003 (2020)

5. S. A. Voronov, I. A. Kiselev, Mashinostroenie i inzhenernoe obrazovanie, 2, (51), 9 (2017)

6. R. Rusinek, M. Wiercigroch, P. Wahi, Int. J. Mech. Sci., 89, 167 (2014)

7. S. Yamnikov, L. L. Safarova, Chernye metally, 9, 68-72 (2020)

8. S. Yamnikov, L. L. Safarova, J. of Mach. Manuf. and Reliab., 49(12) 1041-1046 (2020)

9. S. Yamnikov, L. L. Safarova, AIP Conf. Proc., 2340, 060002 (2021)

10. S. Yamnikov, L. L. Safarova, Chernye metally, 11, 47-51 (2019)

11. V. I. Averchenkov, A. S. Vasilyev, M. L. Kheifets, Naukoyomkiye tekhnologii v mashinostroyenii. 10 (88), 27-32 (2018).

12. S. Vasilyev, Vestnik Rybinskoy gosudarstvennoy aviatsionnoy tekhnologicheskoy akademii im. P. A. Solovyeva. 1 (40). 198-202. (2017)

13. W. Zhenting, G. Hongming, Advanced Materials Research, 1061-1062, 670-673 (2015)

14. M. Gromczyk, M. Kondracki, A. Studnicki, D. Szajnar, Archives of Foundry Engineering, 15, 2 (2015)

15. S. Biswas, C. Monroe, T. Prucha, Int. J. of Metalcasting, 11, 4 656-674 (2017)

16. E. A. Dronov, V. I. Barakhov, V. N. Samochkin, Izvestiya TulGU. Tekhnicheskiye nauki, 12(2) 39-47 (2016)

17. P. Babichev, Honing: [monograph], VolgGASU, 245 (2013)

18. R. Joliet, M. Kansteiner, P. Kersting, Procedia CIRP, 28, 46-51 (2015)

19. G. Shaowu, Y. Changyong, X. Jiuhua, S. Hao, F. Yucan, Proc. Manuf., 26, 462-468 (2018)

20. M. Pehl, A. Arvesen, F. Humpenöder, A. Popp, E. G. Hertwich, G. Luderer, Nature Energy, 2, 939-945 (2017) 